Article

\title{
Variation of Deoxynivalenol Levels in Corn and Its Products Available in Retail Markets of Punjab, Pakistan and Estimation of Risk Assessment
}

\begin{abstract}
The study focused on investigating the natural incidence of deoxynivalenol (DON) in corn and products from corn producing districts of Punjab, Pakistan. The analysis was carried out using HPLC with UV detector and immunoaffinity cleanup columns. The detection limit (LOD) and limit of quantification were 25 and $50 \mu \mathrm{g} / \mathrm{kg}$, respectively. Total 1220 samples of corn and products were analyzed to detect the DON, and 539 (44.2\%) samples were observed to be contaminated with DON ( $n \geq$ LOD). Furthermore, 92 (7.5\%) samples of corn and corn products have DON levels, elevated than the proposed limits of the EU. The data is significantly different from a normal distribution for DON in corn and products samples and from different locations $(\mathrm{p}<0.05)$ for Shapiro-Wilk and Kolmogorov-Smirnov values. However, a significant difference in DON levels was found between corn and corn derived-products types ( $\mathrm{p} \leq 0.05)$. The lowest and highest exposure, and hazard quotient (HQ) of 0.92 and $9.68 \mu \mathrm{g} / \mathrm{kg}$ bw/d were documented in corn flour samples.
\end{abstract}

Keywords: DON; corn; corn products; exposure; risk assessment

Key contribution: A total of 1220 samples of corn and corn products from three districts of Punjab were analyzed for DON. Samples $539(44.2 \%)$ of corn and corn products were found to be positive with DON ( $\mathrm{n} \geq$ LOD). Samples $92(7.5 \%)$ of corn and corn products having levels of DON greater than the proposed limits of EU $(1000 \mu \mathrm{g} / \mathrm{kg} ; 750 \mu \mathrm{g} / \mathrm{kg})$. The lowest and highest exposure \& HQ level of 0.92 and $9.68 \mu \mathrm{g} / \mathrm{kg}$ bw/d were documented in corn flour samples

\section{Introduction}

Corn (Zea mays) is the third main producing crop in Pakistan after wheat and rice. Its share in total cereal cultivations area is $8.5 \%, 2.2 \%$ to the value-added in the agriculture sector, and $0.4 \%$ to gross domestic product (GDP). Corn plays a vital role in the country's economy by its multiple uses for domestic, commercial, and industrial purposes. In 201718 , corn production is predicted 5.8 million tons, 3 percent higher than the previous year reflects its demands in-country. The hybrid corn is cultivated about $40 \%$ of the corn area, and its share in total corn production is around $70 \%$. About $65 \%$ of corn is utilized in the poultry industry, $10 \%$ in dairy feed, $15 \%$ in wet milling, and remaining for human consumption and seeds [1]. Corn is the cereal prone to be attacked by fungus and thus subsequently for mycotoxins production (e.g., DON) [2,3].

Mycotoxins are recognized as secondary metabolites and produced by fungi, mainly Aspergillus, Penicillium, Fusarium, Alternaria, and Cladosporium [4-7]. Fusarium is widely dispersed in nature and cause spoilage or deterioration of food and feeds 8]. DON, also identified as vomitoxin, is a secondary fungal metabolite to the class of trichothecenes and produced by the genus Fusarium, especially F.graminearum [9-13]. The previous studies have documented the toxic effects of trichothecenes, such as feed refusal, hemorrhage vomiting, diarrhea, anemia and immunosuppression [14-16].

In previous study, 63 out of 100 samples were found to be contaminated with DON as documented by Raza et al. [17], from rural, semi-rural and urban areas from central cities of Punjab, Pakistan. The results had indicated that $63 \%$ samples of corn were contaminated with DON, and from these samples almost $66 \%$ samples have levels higher than $1250 \mu \mathrm{g} / \mathrm{kg}$. Furthermore, $49.2 \%$ samples have levels highly than $1401 \mu \mathrm{g} / \mathrm{kg}$. The 
results have indicated that the levels were higher in samples from rural areas samples for both in corn $(1512 \mu \mathrm{g} / \mathrm{kg})$ and wheat $(1585 \mu \mathrm{g} / \mathrm{kg})$ grains. Similarly, the effect of seasonal variation on the levels of DON in wheat and corn samples were investigated from Punjab, Pakistan [18]. The results have shown that 87 (61.2\%) samples of corn and corn products from summer and 57 (44.5\%) from winter season were found to be contaminated with concentration ranged from 50 to $2967 \mu \mathrm{g} / \mathrm{kg}$, and 50 to $2490 \mu \mathrm{g} / \mathrm{kg}$, respectively.

The countries and organization have established maximum limits for DON in raw and processed cereal products. The Codex Alimentarius Commission has established permissible limit of $2000 \mu \mathrm{g} / \mathrm{kg}$ in raw barley, wheat, and corn. Similarly, EU has also established a limit of $2000 \mu \mathrm{g} / \mathrm{kg}$ in unprocessed wheat, and oat. However, a permissible legal limit of $1000 \mu \mathrm{g} / \mathrm{kg}$ for raw or those cereals which would be unprocessed, and $750 \mu \mathrm{g} / \mathrm{kg}$ for foodstuffs, intended for consumers and dry pasta and $200 \mu \mathrm{g} / \mathrm{kg}$ for snacks and breakfast cereals used for children [ 19]. The tolerance daily intake for DON is proposed as 1 $\mu \mathrm{g} / \mathrm{kg} / \mathrm{bw}$ per day.

Pakistan is located in a tropical part, and therefore, the environmental conditions are encouraging for fungal growth and production $[5,20]$. Although corn is a major cash crop and previous studies have shown, this substrate is more vulnerable to fungi attack and contamination. However, there is not enough information available on the prevalence of DON in corn-derived foods in Pakistan. Consequently, the existing study was designed to examine the incidence levels of DON in corn and corn-derived products and compare the levels with EU recommended regulations. The exposure assessment of DON in corn and products will also help disseminate the information to farmers, traders, and other stakeholders in Pakistan.

\section{Results}

\subsection{Method Validation}

The recoveries analysis of DON in corn and corn products were performed as presented in Table 1. The recoveries were in the range of 81.3 to $91.0 \%$, and the relative standard deviation was varied from 11 to $28 \%$. The detection limit (LOD) and limit of quantification (LOQ) were $25 \mu \mathrm{g} / \mathrm{kg}$ and $50 \mu \mathrm{g} / \mathrm{kg}$, respectively. The straight-line equation was constructed, and the coefficient of determination (0.9992) was obtained.

Table 1. Recovery percentage of DON in corn and products.

\begin{tabular}{|c|c|c|c|c|c|c|c|c|c|c|c|c|c|c|c|c|}
\hline \multirow{2}{*}{$\begin{array}{l}\text { DON } \\
\text { level }\end{array}$} & \multicolumn{4}{|c|}{ Corn (mix) } & \multicolumn{4}{|c|}{ Corn flour } & \multicolumn{4}{|c|}{ Cornbread } & \multicolumn{4}{|c|}{ Sweet Corn } \\
\hline & Recovery & RSD & Precis & ion $(\%)$ & Recovery & y RSD & Precis & $\operatorname{sion}(\%)$ & ecovery & RSD & Precis & ision (\%) & Recovery & RSD & Preci & $\operatorname{sion}(\%)$ \\
\hline$\mu \mathrm{g} / \mathrm{Kg}$ & $(\%)$ & $(\%)$ & $\operatorname{Rep}^{a}$ & $\underset{\mathrm{b}}{\text { Reprod }}$ & $(\%)$ & $\%)$ & $\operatorname{Rep}^{a}$ & $\underset{\mathrm{b}}{\text { Reprod }}$ & $(\%)$ & $(\%)$ & $\operatorname{Rep}^{a}$ & Reprod $^{b}$ & $(\%)$ & $(\%)$ & $\operatorname{Rep}^{a}$ & Reprod $^{b}$ \\
\hline 100 & 84.5 & 16 & 11 & 21 & 81.5 & 11 & 12 & 19 & 89.5 & 14 & 9 & 20 & 85.2 & 16 & 10 & 21 \\
\hline 150 & 89.5 & 11 & 18 & 19 & 86.5 & 14 & 09 & 15 & 83.5 & 18 & 15 & 26 & 89.5 & 17 & 14 & 17 \\
\hline 300 & 88.0 & 22 & 15 & 22 & 87.4 & 17 & 16 & 22 & 90.5 & 23 & 10 & 18 & 89.5 & 15 & 9 & 21 \\
\hline 400 & 91.0 & 13 & 18 & 24 & 90.9 & 12 & 14 & 20 & 89.5 & 22 & 12 & 22 & 88.4 & 19 & 17 & 26 \\
\hline 800 & 88.8 & 23 & 10 & 22 & 86.1 & 16 & 18 & 26 & 88.4 & 21 & 15 & 20 & 85.2 & 21 & 15 & 24 \\
\hline 3000 & 85.0 & 21 & 18 & 28 & 84.0 & 20 & 20 & 27 & 85.5 & 20 & 18 & 27 & 81.3 & 28 & 18 & 28 \\
\hline
\end{tabular}

$\mathrm{RSD}=$ relative standard deviation, $\mathrm{LOD} 25 \mu \mathrm{g} / \mathrm{kg}, \mathrm{LOQ}=50 \mu \mathrm{g} / \mathrm{kg}$, a = Repeatability, $\mathrm{b}=$ Reproducibility.

\subsection{Incidence of DON in Corn and Products}

The occurrence of DON in 1220 samples of corn and corn products ( 449 samples from Gujranwala, 378 from Hafizabad, and 393 samples from Sheikhupura) were presented in Table 2-4, respectively. Samples 539 (44.2\%) were found to be positive ( $\mathrm{n} \geq \mathrm{LOD}$ ) with DON in corn and products. In 449 samples from Gujranwala, 197 (43.9\%) samples of corn and corn products were found to be positive with DON (Table 2). 
Table 2. Occurrence of DON in corn and corn products from Gujranwala, Punjab, Pakistan.

\begin{tabular}{ccccc}
\hline Sample type & $\begin{array}{c}\text { Samples } \\
\mathbf{N}\end{array}$ & $\begin{array}{c}\text { Positive } \\
\mathbf{N}(\boldsymbol{\%})\end{array}$ & $\begin{array}{c}\text { Mean } \\
(\boldsymbol{\mu g} / \mathbf{k g}) \pm \mathbf{S . D} .\end{array}$ & $\begin{array}{c}\text { Range } \\
(\boldsymbol{\mu g} / \mathbf{k g})\end{array}$ \\
\hline Corn 1 & 40 & $18(45.0)$ & $1256.2 \pm 124.5$ & $25-5687.5$ \\
\hline Corn 2 & 45 & $22(48.9)$ & $1126.2 \pm 90.8$ & $25-5568.6$ \\
\hline Corn 3 & 54 & $15(27.8)$ & $1049.7 \pm 110.5$ & $25-5678.5$ \\
\hline Corn 4 & 41 & $22(53.7)$ & $909.8 \pm 120.5$ & $25-4550.5$ \\
\hline Corn flour & 60 & $34(57.6)$ & $854.7 \pm 40.7$ & $25-8990.5$ \\
\hline Sweet corn & 83 & $30(36.1)$ & $556.5 \pm 80.6$ & $25-4550.5$ \\
\hline Corn bread & 35 & $18(51.4)$ & $86.6 \pm 14.5$ & $25-450.5$ \\
\hline Corn oil & 56 & $22(39.3)$ & $88.8 \pm 15.5$ & $25-980.5$ \\
\hline Popcorns & 35 & $16(45.7$ & $41.4 \pm 10.5$ & $25-95.5$ \\
\hline Total & 449 & $197(43.9)$ & & $25-8990.5$ \\
\hline Corn
\end{tabular}

Corn $1=$ corn variety; corn $2=$ corn variety; corn 3 = Corn variety; corn $4=$ Corn variety, $\mathrm{N}(\%)=\mathrm{n}$ (percentage of samples), $\mathrm{LOD}=25 \mu \mathrm{g} / \mathrm{kg}$.

The maximum average of $1256.2 \pm 124.5 \mu \mathrm{g} / \mathrm{kg}$ of DON was found in corn type 1 samples and varied from 25 to $5687.5 \mu \mathrm{g} / \mathrm{kg}$. Table 3, $166(43.9 \%)$ out of 378 samples of corn and products from Hafizabad, were positive with the maximum average of $(1489.4 \pm$ $190.8 \mu \mathrm{g} / \mathrm{kg}$ ) in corn type 4 samples, ranged from 25-5540.5 $\mu \mathrm{g} / \mathrm{kg}$. Furthermore, 176 $(44.8 \%)$ out of 393 samples of corn and products from Sheikhupura were found to be contaminated with DON, and the maximum average $(1489.4 \pm 180.5 \mu \mathrm{g} / \mathrm{kg})$ was found in corn type 4 samples with concentration ranged from $25-5540.5 \mu \mathrm{g} / \mathrm{kg}$. About $92(7.5 \%)$ samples of corn and corn products were found to be contaminated with DON greater than EU [19] proposed limits as represented in Figure 1.

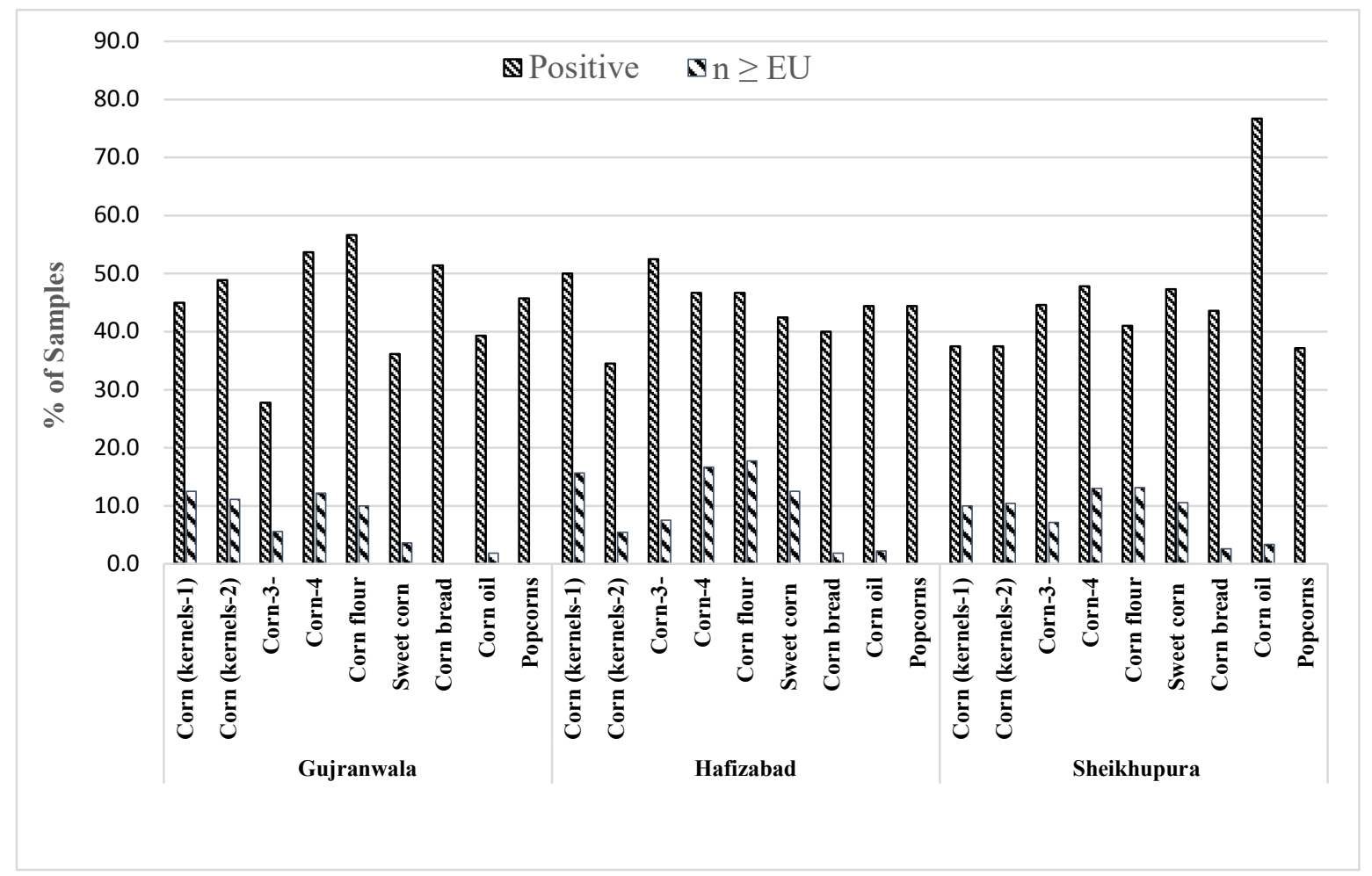

Figure 1. Percentage of sample of corn and corn products having levels of DON higher than recommended limits of EU $(1000 \mu \mathrm{g} / \mathrm{kg}$ for unprocessed corn and $750 \mu \mathrm{g} / \mathrm{kg}$ for foodstuff) . 
Table 3. Occurrence of DON in corn and corn products from Hafizabad, Punjab, Pakistan.

\begin{tabular}{ccccc}
\hline Sample type & $\begin{array}{c}\text { Samples } \\
\mathbf{N}\end{array}$ & $\begin{array}{c}\text { Positive } \\
\mathbf{N}(\boldsymbol{\%})\end{array}$ & $\begin{array}{c}\text { Mean } \\
(\boldsymbol{\mu g} / \mathbf{k g}) \pm \mathbf{S . D} .\end{array}$ & $\begin{array}{c}\text { Range } \\
(\boldsymbol{\mu g} / \mathbf{k g})\end{array}$ \\
\hline Corn 1 & 32 & $16(50.0)$ & $1187.3 \pm 210.5$ & $25-6660.5$ \\
\hline Corn 2 & 55 & $19(34.5)$ & $1081.6 \pm 140.3$ & $25-6590.6$ \\
\hline Corn 3 & 40 & $21(52.5)$ & $808.2 \pm 70.5$ & $25-5640.5$ \\
\hline Corn 4 & 30 & $14(46.7)$ & $1489.4 \pm 190.8$ & $25-5540.5$ \\
\hline Corn flour & 45 & $21(46.7)$ & $1030.8 \pm 105.4$ & $25-7860.5$ \\
\hline Sweet corn & 40 & $17(42.5)$ & $471.1 \pm 20.5$ & $25-2345.5$ \\
\hline Corn bread & 55 & $22(40.0)$ & $97.3 \pm 15.5$ & $25-500.5$ \\
\hline Corn oil & 45 & $20(44.4)$ & $88.3 \pm 9.5$ & $25-540.5$ \\
\hline Popcorns & 36 & $16(44.4)$ & $42.2 \pm 4.5$ & $25-80.5$ \\
\hline Total & 378 & $166(43.9)$ & & $25-7860.5$ \\
\hline Corn
\end{tabular}

Corn $1=$ corn variety; $\operatorname{corn} 2=$ corn variety; corn 3 = corn variety; corn $4=$ corn variety,

$\mathrm{N}(\%)=\mathrm{n}$ (percentage of samples), $\mathrm{LOD}=25 \mu \mathrm{g} / \mathrm{kg}$.

Table 4. Occurrence of DON in corn and corn products from Sheikhupura, Punjab, Pakistan.

\begin{tabular}{ccccc}
\hline Sample type & $\begin{array}{c}\text { Samples } \\
\mathbf{N}\end{array}$ & $\begin{array}{c}\text { Positive } \\
\mathbf{N}(\mathbf{\%})\end{array}$ & $\begin{array}{c}\text { Mean } \\
(\boldsymbol{\mu g} / \mathbf{k g}) \pm \mathbf{S . D} .\end{array}$ & $\begin{array}{c}\text { Range } \\
(\boldsymbol{\mu g} / \mathbf{k g})\end{array}$ \\
\hline Corn 1 & 48 & $15(37.5$ & $1187.3 \pm 230$ & $25-6660.5$ \\
\hline Corn 2 & 48 & $18(37.5)$ & $1081.6 \pm 145.5$ & $25-6590.6$ \\
\hline Corn 3 & 56 & $25(44.6)$ & $808.2 \pm 60.5$ & $25-5640.5$ \\
\hline Corn 4 & 46 & $22(47.8)$ & $1489.4 \pm 180.5$ & $25-5540.5$ \\
\hline Corn flour & 61 & $25(41.0)$ & $1030.8 \pm 170.5$ & $25-7860.5$ \\
\hline Sweet corn & 38 & $18(47.4)$ & $471.1 \pm 30.5$ & $25-2345.5$ \\
\hline Corn bread & 39 & $17(43.6)$ & $97.3 \pm 15.5$ & $25-500.5$ \\
\hline Corn oil & 30 & $23(76.7)$ & $88.3 \pm 9.5$ & $25-540.5$ \\
\hline Popcorns & 35 & $13(37.1)$ & $42.1 \pm 4.5$ & $25-90.5$ \\
\hline Total & 393 & $176(44.8)$ & & $25-7860$ \\
\hline
\end{tabular}

Corn $1=$ variety of corn; corn $2=$ corn variety; $\operatorname{corn} 3$ = variety of corn; corn $4=$ variety of corn, $\mathrm{N}$

$(\%)=\mathrm{n}$ (percentage of samples), $\mathrm{LOD}=25 \mu \mathrm{g} / \mathrm{kg}$.

The data is significantly different from a normal distribution of DON's levels in different types of corn and products and to different locations, considering the high values of skewness and kurtosis and $p \leq 0.00$ for Shapiro-Wilk Kolmogorov-Smirnov values. The ANOVA of DON levels in different corn and corn products was statistically significant $(\mathrm{p}$ $\leq 0.000)$. The amounts of DON in corn and corn products from different locations were non-significant ( $\mathrm{p} \geq 0.05)$, as shown in Table 5a. The least significant difference (LSD) of which type of corn and corn products were significant compared to other types are shown in Table $5 b$.

Table 5a.: ANOVA of DON levels in corn and corn products and from various locations.

\begin{tabular}{ccccccc}
\hline & & Sum of Squares & df & Mean Square & F & Sig \\
\hline DON level & Between Groups & 96192972.7 & 8 & 12024121.6 & 8.132 & 0.000 \\
\hline & Within Groups & 783676623.6 & 530 & 1478635.1 & & \\
\hline Total & 879869596.4 & 538 & & & \\
\hline Location & Between Groups & 4.737 & 8 & & & \\
\hline & Within Groups & 367.4 & 530 & 0.592 & 0.854 & 0.555 \\
\hline & Total & 372.2 & 538 & 0.693 & & \\
\hline
\end{tabular}


Table 5b: LSD analysis of different types of corn and corn products within groups samples.

\begin{tabular}{|c|c|c|c|c|c|}
\hline & & Corn products & Mean difference & Std. Error & Significance \\
\hline \multirow[t]{42}{*}{ Don Level } & Corn 1 & Sweet corn & 629.92 & 230.05 & 0.006 \\
\hline & & Corn bread & 1066.63 & 236.89 & 0.000 \\
\hline & & Corn oil & 1073.58 & 230.05 & 0.000 \\
\hline & & Popcorns & 1130.06 & 251.06 & 0.000 \\
\hline & Corn 2 & Sweet corn & 542.88 & 218.65 & 0.013 \\
\hline & & Corn bread & 979.59 & 225.83 & 0.000 \\
\hline & & Corn oil & 986.53 & 218.65 & 0.000 \\
\hline & & Popcorns & 1043.03 & 240.66 & 0.000 \\
\hline & Corn 3 & Corn bread & 842.21 & 224.01 & 0.000 \\
\hline & & Corn oil & 849.16 & 216.76 & 0.000 \\
\hline & & Popcorns & 9.05 .65 & 238.95 & 0.000 \\
\hline & Corn 4 & Sweet corn & 483.11 & 219.64 & 0.028 \\
\hline & & Corn bread & 919.82 & 226.79 & 0.000 \\
\hline & & Corn oil & 926.77 & 219.64 & 0.000 \\
\hline & & Popcorns & 983.26 & 241.56 & 0.000 \\
\hline & Corn flour & Corn bread & 772.55 & 210.76 & 0.000 \\
\hline & & Corn oil & 779.50 & 203.05 & 0.000 \\
\hline & & Corn popcorns & 8.35 .99 & 226.58 & 0.000 \\
\hline & Sweet corn & Corn Type 1 & -629.91 & 230.05 & 0.006 \\
\hline & & Corn type 2 & -542.88 & 218.65 & 0.013 \\
\hline & & Corn type 4 & -483.11 & 219.64 & 0.028 \\
\hline & & Corn bread & 436.70 & 220.65 & 0.048 \\
\hline & & Corn oil & 443.65 & 213.29 & 0.038 \\
\hline & & Popcorns & 500.15 & 235.81 & 0.034 \\
\hline & Corn bread & Corn Type 1 & -1066.62 & 236.89 & 0.000 \\
\hline & & Corn type 2 & -979.59 & 225.83 & 0.000 \\
\hline & & Corn type 3 & -842.21 & 224.01 & 0.000 \\
\hline & & Corn type 4 & -919.82 & 226.79 & 0.000 \\
\hline & & Corn flour & -772.55 & 210.76 & 0.000 \\
\hline & & Sweet corn & -436.70 & 220.65 & 0.048 \\
\hline & Corn oil & Corn Type 1 & -1073.57 & 230.05 & 0.000 \\
\hline & & Corn type 2 & -986.53 & 218.65 & 0.000 \\
\hline & & Corn type 3 & -849.15 & 216.76 & 0.000 \\
\hline & & Corn type 4 & -926.73 & 219.64 & 0.000 \\
\hline & & Corn flour & -779.50 & 203.05 & 0.000 \\
\hline & & Sweet corn & -443.65 & 213.29 & 0.038 \\
\hline & Popcorns & Corn Type-1 & -1130.06 & 251.06 & 0.000 \\
\hline & & Corn type 2 & -1043.03 & 240.66 & 0.000 \\
\hline & & Corn type 3 & -905.65 & 238.95 & 0.000 \\
\hline & & Corn type 4 & -983.26 & 241.56 & 0.000 \\
\hline & & Corn flour & -835.99 & 226.58 & 0.000 \\
\hline & & Sweet corn & -500.15 & 235.81 & 0.034 \\
\hline
\end{tabular}

d.f. $=$ degree of freedom; $F=F$ test; significance $=p$ value

\subsection{Estimation of Exposure Assessment of DON in Cornflour}

The assessment of exposure of DON levels in corn flour from different locations is presented in Table 6. The DON's highest exposure was $9.68 \mu \mathrm{g} / \mathrm{kg} \mathrm{bw} / \mathrm{d}$, and the lowest exposure was $0.92 \mu \mathrm{g} / \mathrm{kg}$ bw/d in corn flour samples from Gujranwala, District.

Table 6. Exposure assessment of DON in corn flour from corn producing cities of Punjab, Pakistan.

\begin{tabular}{|c|c|c|c|c|c|c|c|c|c|c|c|c|c|}
\hline & \multirow{3}{*}{$\begin{array}{c}\text { Consumption } \\
(\mathrm{kg})\end{array}$} & \multicolumn{4}{|c|}{ Gujranwala } & \multicolumn{4}{|c|}{ Hafizabad } & \multicolumn{4}{|c|}{ Sheikhupura } \\
\hline & & \multicolumn{2}{|c|}{ DON levels } & \multicolumn{2}{|c|}{ Exposure } & \multicolumn{2}{|c|}{ DON levels } & \multicolumn{2}{|c|}{ Exposure } & \multicolumn{2}{|c|}{ DON levels } & \multicolumn{2}{|c|}{ Exposure } \\
\hline & & $\begin{array}{l}\text { Mean } \\
\mu \mathrm{g} / \mathrm{kg}\end{array}$ & $\begin{array}{c}\text { Highest } \\
\text { level } \\
\mu \mathrm{g} / \mathrm{kg}\end{array}$ & $\begin{array}{l}\text { Mean } \\
\mu \mathrm{g} / \mathrm{kg} \\
\mathrm{bw} / \mathrm{d}\end{array}$ & $\begin{array}{c}\text { Highest } \\
\mu \mathrm{g} / \mathrm{kg} \\
\text { bw/d }\end{array}$ & $\begin{array}{l}\text { Mean } \\
\mu \mathrm{g} / \mathrm{kg}\end{array}$ & $\begin{array}{c}\text { Highest } \\
\text { level } \\
\mu \mathrm{g} / \mathrm{kg}\end{array}$ & $\begin{array}{l}\text { Mean } \\
\mu \mathrm{g} / \mathrm{kg} \\
\mathrm{bw} / \mathrm{d}\end{array}$ & $\begin{array}{c}\text { Highest } \\
\mu \mathrm{g} / \mathrm{kg} \\
\text { bw/d }\end{array}$ & $\begin{array}{l}\text { Mean } \\
\mu \mathrm{g} / \mathrm{kg}\end{array}$ & $\begin{array}{c}\text { Highest } \\
\text { level } \\
\mu \mathrm{g} / \mathrm{kg}\end{array}$ & $\begin{array}{l}\text { Mean } \\
\mu \mathrm{g} / \mathrm{kg} \\
\mathrm{bw} / \mathrm{d}\end{array}$ & $\begin{array}{c}\text { Highest } \\
\mu \mathrm{g} / \mathrm{kg} \\
\mathrm{bw} / \mathrm{d}\end{array}$ \\
\hline $\begin{array}{l}\text { Corn } \\
\text { flour }\end{array}$ & 0.07 & 854.7 & 8990.5 & 0.92 & 9.68 & 1030.8 & 7860.5 & 1.11 & 8.47 & 1030.8 & 7860.5 & 1.11 & 8.47 \\
\hline $\mathrm{HQ}^{1}$ & & & & 0.92 & & & & 1.11 & & & & 1.11 & \\
\hline $\mathrm{HQ}^{2}$ & & & & & 9.68 & & & & 8.47 & & & & 8.47 \\
\hline
\end{tabular}

$\mathrm{HQ}^{1}=$ mean level of $\mathrm{DON}, \mathrm{HQ}^{2}=$ highest level of $\mathrm{DON}$. 


\section{Discussion}

\subsection{Method Validation}

The results have shown that the analytical parameters like accuracy and precision of DON in corn and corn products were within the European Commission's recommended guidelines [22]. According to the guidelines, the recoveries of DON should be within 60 $\%$ to $110 \%$, and the repeatability and reproducibility should be $\leq 20 \%$ and $\leq 40 \%$, respectively. Furthermore, for DON value $>500 \mu \mathrm{g} / \mathrm{kg}$ level, the recommendations are 70 to $120 \%$ recoveries, and repeatability and reproducibility must be less than $20 \%$ and $40 \%$, respectively [22-23]. The determination coefficient was $\geq 0.999$, and LOD and LOQ were 25 and $50 \mu \mathrm{g} / \mathrm{kg}$, respectively. The coefficient of determination was quite similar with the value from our previous study Iqbal et al. [18]. However, the LOD and LOQ are much lower in the current study. Ok et al. [23] have documented the value of the coefficient of determination $\geq 0.999$, and LOD and LOQ were 6.4 to $10.0 \mu \mathrm{g} / \mathrm{kg}$ and 21.3 to $33.5 \mu \mathrm{g} / \mathrm{kg}$. Yang et al. [24] have demonstrated the LOD of $12.2 \mu \mathrm{g} / \mathrm{kg}$ for DON in corn samples using SPE cleanup. In another study, relatively high LOD and LOQ for DON, i.e., 30 and 40 $\mu \mathrm{g} / \mathrm{kg}$, were documented in milling fractions of wheat using multifunctional column cleanup [25]. Golge and Kabak, [26] have determined the LOQ of 46.90 to $72.30 \mu \mathrm{g} / \mathrm{kg}$ of DON in various cereal products, higher than the LOQ of the present study.

\subsection{Incidence of DON in Corn and Corn Products}

The results have demonstrated comparatively high DON in corn and corn products from three districts, i.e., Gujranwala, Hafizabad, and Sheikhupura of Punjab, Pakistan. In our previous study, [18] we have investigated the seasonal variation of DON levels in corn and corn products and documented that samples from summer have a higher incidence, i.e., $87(61.2 \%)$ as compared to the samples from the winter season (44.5\%). The maximum average observed was $1434.8 \pm 25.5 \mu \mathrm{g} / \mathrm{kg}$ in corn flour samples from the summer season, and the lowest mean level was found in cornbread $620.8 \pm 17.8 \mu \mathrm{g} / \mathrm{kg}$, from the winter season. A high incidence level of DON compared to the present finding results was observed from Spain, and almost $68 \%$ of commercial corn-based food samples were found to be positive, with levels ranged from 29 to $195 \mu \mathrm{g} / \mathrm{kg}$ [27]. From Turkey, Golge, and Kabak [26] have observed 13 wheat samples (58 to $1092 \mu \mathrm{g} / \mathrm{kg}$ ), three barley (138 to 973 $\mu \mathrm{g} / \mathrm{kg}$ ), seven paddy rice (136 to $256 \mu \mathrm{g} . \mathrm{kg}$ ), three wheat flour (92 to $151 \mu \mathrm{g} / \mathrm{kg}$ ), two biscuits $(31.2$ to $71.3 \mu \mathrm{g} / \mathrm{kg})$, and one pasta sample $(59.3 \mu \mathrm{g} / \mathrm{kg})$. However, two corn samples were found contaminated with DON (313 to $331 \mu \mathrm{g} / \mathrm{kg}$ ). All the samples have levels below the recommended EU limits.

The high amount of DON (42 to $4130 \mu \mathrm{g} / \mathrm{kg}$ with a average amount of $977 \pm 1000$ $\mu \mathrm{g} / \mathrm{kg}$ ) in wheat and cereals samples from Austria, Germany, Slovakia, and Australia [28], was documented. From Cameroon, Njobeh et al. [29] documented 65\% samples out of 82 samples of dried food commodities with DON levels ranged from 13 to $273 \mu \mathrm{g} / \mathrm{kg}$. High occurrence and maximum amount of DON in corn compared to the current study results were reported by Paladin et al. [30] from Croatia. They reported $85 \%$ of samples were found positive with the highest concentration of $17920 \mu \mathrm{g} / \mathrm{kg}$. In Portugal, Marques et al. [31] have analyzed 307 samples of plant crops, the mean of DON concentrations $70 \mu \mathrm{g} / \mathrm{kg}$, the highest amount was $17,900 \mu \mathrm{g} / \mathrm{kg}$, respectively. Vidal et al. [32] from Spain have observed DON in $42 \%$ bran samples with the highest amount of $6178 \mu \mathrm{g} / \mathrm{kg}$, and thirteen samples (19\%) exceeded the EU allowable limit. Serbia, Jajić et al. [33] have documented that $32 \%$ of corn samples were discovered to be contaminated, and $86 \%$ of samples were discovered contaminated with DON from Hungary [34].

However, earlier studies have documented low levels of DON compare to the findings of the present survey. Escobar et al. [3], from Spain, have analyzed 25 corn oils samples with mean levels of DON were $31 \mu \mathrm{g} / \mathrm{kg}$. Similarly, Giménez et al. [35], from Spain, have found 10 out of 25 wheat germ oil samples with mean levels of DON $41 \mu \mathrm{g} / \mathrm{kg}$.

It is worth mentioning that regional variation was found in DON levels. Hot weather conditions promote the formation of fusarium-producing fungi and the production of mycotoxins [36]. The elevated prevalence of DON in the summer season compared to the 
winter season in corn and corn products has been confirmed in our previous study [17]. Fernandez et al. [37], from the US, have documented lower DON levels in cereal samples than the levels reported by Ngoko et al. [38] in corn from Cameroon. The temperate environmental conditions favor the production of DON [39]. Furthermore, high levels of humidity as a combination of high temperature could enhance fungi growth rate belongs to genus Fusarium [40]. The variation in sampling size is another factor that should be considered a significant source of variation in mycotoxins [41]. The elevated amount of DON in corn and corn products could be explained because farmers in Pakistan still use old traditional methods in rural areas with cheap varieties of corn and not using crop rotation or no-tilled. Furthermore, the storage of corn in mud bins could also enhance the contamination of cereal crops [42].

\subsection{Exposure Assessment of DON in Cornflour}

In our previous study Iqbal et al. [18], from the summer season, the maximum exposure of DON was observed in wheat flour, i.e., $8.8 \mu \mathrm{g} / \mathrm{kg}$ b.w/day. According to WHO, [43], if ADD > PMTDI, then the potential for health risk exists. The individual or population may suffer a health risk if $H Q>1$. The health risks were limited if individual or population exposed the espouse of DON less than 1 i.e., If $\mathrm{HQ}<1$. The exposure of 1.052 $\mu \mathrm{g} / \mathrm{kg}$ b.w/day of DON was estimated in bread and toasts [44], comparable to the exposure of DON in current research. The exposure of 0.027 to $0.038 \mu \mathrm{g} / \mathrm{kg} \mathrm{b.w} /$ day was observed by Cano-Sancho et al. [45]. The high level of 1.11 of HQ from current research from Hafizabad and Sheikhupura districts could cause serious risk factors in the local population.

\section{Conclusions}

Evaluating the research findings and evaluating them to the legitimate limit of the EU for mycotoxins in current work reflects that the prevalence and amounts of DON were comparatively high. About $7.5 \%$ of samples of corn and corn products were contaminated with DON at levels greater than the EU suggested limits. The exposure and HQ amount of DON in corn and products were also high. Adopting good storage practices would reduce the level of DON in cereals because generally, in Pakistan, the cereals crops are stored and transported in jute bags. The jute bags could absorb moisture from the environment or surface where the crop was stored. The recommendation could be to store these crops in polyethylene bags during transport and storage area. Furthermore, the moisture, humidity, and temperature should be controlled during the storage period, and farmers should use resistant crop varieties. In-vivo study of DON levels in blood and urine in local consumers should be more desirable for the assessment of exposure and implementation of regulations in population.

\section{Materials and Methods}

\subsection{Sampling}

The 1220 samples of corn and products (corn flour, sweet corn, cornbread, corn oil, and popcorn) from three Punjab districts ( $\mathrm{n}=449$ Gujranwala, $n=378$ Hafizabad, $n=393$ Sheikhupura) were collected during June 2018 to January 2019. A simple random methodology (each portion or lot has equal chance to be included) was used for collecting corn and corn products samples from farmers, market, and superstores. The gross samples were taken by hands and then homogenized and proper labelling was done. These three districts are most famous for producing corn in Punjab, Pakistan. Due to the high variability of fungi and mycotoxins in kernel samples, each sample size was not less than $2 \mathrm{~kg}$. Then the kernel samples were mixed and ground in adequate particle size (Retsch, ZM 200, Haan, Düsseldorf, Germany). The lab sample portion was stored in plastic bags and kept in the freezer at $-20^{\circ} \mathrm{C}$.

\subsection{Chemicals and Reagents}


A pure standard of DON (100 mg/mL in ACN) from Sigma Aldrich (Saint-Louis, MO, USA) was available in the lab (Food Safety lab). High-grade purity ( $\geq 99 \%$ ) solvents of acetonitrile, methanol, and polyethylene glycol 8000 (PEG), were acquired from SigmaAldrich (Sigma-Aldrich, Lyon, France). The method's linearity was assessed with sevenpoint concentrations $(100,200,800,1600,3200,6400$, and $9000 \mu \mathrm{g} / \mathrm{kg}$ ) of DON and stored in caped vials at temperature $-20^{\circ} \mathrm{C}$. All other chemicals used were of analytical grade and available in the lab.

\subsection{Extraction and HPLC Parameters}

The extraction of DON in corn and products were carried out using our previously validated method [17]. Briefly, the sample $(5 \mathrm{~g})$ and PEG $(1 \mathrm{~g})$ were mixed in $20 \mathrm{~mL}$ of ultra-pure water and homogenized in $50 \mathrm{~mL}$ of Teflon tubes, and centrifuged at room temperature for one minute at $6500 \mathrm{pm}$. The extraction of cornbread was carried out by adding $200 \mathrm{~mL}$ water on dry bread and then homogenized for 5 minutes at room temperature at $8000 \mathrm{rpm}$ as discussed above. After centrifugation, the mixture was filtered and the filtrate $(5 \mathrm{~mL})$ was passed through to the immunoaffinity column (IAC-NIV WB, columns) (VICAM, Watertown, MA, USA). The column was washed twice with $10 \mathrm{~mL}$ purified water, and the DON was eluted using $1 \mathrm{~mL}$ of pure methanol from the IAC column. Then, $0.5 \mathrm{~mL}$ of pure water was added to $0.5 \mathrm{~mL}$ of eluting and subjected to HPLC analysis, after passing through $0.22 \mu \mathrm{m}$ nylon syringe filters. The Shimadzu (Kyoto, Japan) HPLC system with C18 Supelco column (250 x 4.6 × $5 \mathrm{~mm}$ ) (Discovery HS, Bellefonte, PA, USA). The UV detector (RF-530) was used setting at a detection wavelength of $218 \mathrm{~nm}$. The mobile phase was $30 \%$ methanol and $70 \%$ of water with a flow rate of $1.2 \mathrm{~mL} / \mathrm{min}$.

\subsection{Exposure Assessment}

In the current research, the level of DON in food from literature is considered reasonable. Further, it was believed that the exposure to DON was only through corn flour due to the main ingredient in the Pakistani diet. The mean levels of DON in corn flour and highest levels were used to assess exposure analysis, and an adult body weight is regarded as $65 \mathrm{~kg}$ b.w. The per capita consumption of corn flour was $0.07 \mathrm{~kg}$ [1]). The exposure was assessed using the formula of eq 1 .

$$
\mathrm{ADD}_{\mathrm{DON}}=\frac{C D O N \times I R}{b w} \quad \text { eq-1 }
$$

$\mathrm{ADDON}=$ average daily dose of DON

$\mathrm{CDON}_{\mathrm{D}}=$ Concentration of DON in corn flour

$\mathrm{IR}=$ intake rate of corn flour

bw= body weight

The hazard quotient (HQ) of the mean and highest level of DON in corn flour were also estimated and equaled to exposure assessment studies. The provisional maximum tolerable daily intake (PMTDI) was $1 \mu \mathrm{g} / \mathrm{kg}$ BW for DON [20]. The HQ was determined following the formula shown in eq 2.

$$
\mathrm{HQ}=\frac{\text { ADD DON }}{P M T D I}
$$

\subsection{Method Validation}

All the method validation parameters were performed for the assessment of DON in corn and corn products. The recoveries analysis was performed. The fortified levels (100, $150,300,400,800,3000 \mu \mathrm{g} / \mathrm{kg}$ ) of DON were added in uncontaminated samples of corn and product samples. The LOD and LOQ were assessed as 3:1 and 10:1 of signal-to-noise ratio, respectively.

\subsection{Statistical Analysis}

The results of DON levels in corn and corn products were subjected to statistical analysis using SPSS (version 26 for Windows, SPSS Inc., Chicago, USA). The DON levels in different corn samples and from different locations were checked for normal distribution (Shapiro-Wilks test). ANOVA was applied to investigate the difference of means (DON levels) between different types of corn and products and from different locations. 
The least significant difference (LSD) was used to investigate differences within each type or each location. A probability value of 0.05 was used to determine the statistical significance.

\section{References}

1. USDA. Pakistan: Grain and Feed Annual. GAIN Report Number:PK1707, 2017.Assessed on 24th January 2021.

2. Aniołowska, M.; Steininger, M. Determination of trichothecenes and zearalenone in different corn (Zea mays) cultivars for human consumption in Poland. J. Food Comp. Anal. 2014, 33(1), 14-19.

3. Escobar, J.; Loran, S.; Gimenez, I.; Ferraz, E.; Herrera, M.; Herrera, A.; Arino, A. Occurrence and exposure assessment of Fusarium mycotoxins in maize germ, refined corn oil and margarine. Food Chem. Toxicol. 2013, 62, 514-520.

4. Sweeney M.J., Dobson A.D. Mycotoxin production by Aspergillus, Fusarium and Penicillium species. Int. J. Food Microbiol. 1998, 43, 141-158.

5. Majeed, S.; Asi, M.R.; Iqbal, M.; Iqbal, S.Z.; Jinap, S. Analysis of nutritional traits and comparison of aflatoxins contamination in selected maize varieties from Pakistan. J. Food Prot. 2017, 80 (12), 1993-1998.

6. Iqbal, S.Z.; Asi, M.R.; Jinap, S. Detection of aflatoxins and zearalenone contamination in wheat-derived products. Food Control, 2014, 35 (1), 223-226

7. Agriopoulou, S., Stamatelopoulou, E. Varzakas, T. Advances in occurrence, importance and mycotoxin control strategies: prevention and detoxification in foods. Foods. 2020, 9, 137.

8. Martins, H. M.; Almeida, I.; Marques, M.F.; Guerra, M.M. Fumonisins and deoxynivalenol in corn-based food products in Portugal. Food Chem. Toxicol. 2008, 46, 2585-2587.

9. Marasas, W.F.O. Toxigenic Fusaria. In: Smith, J.E. (Ed.), Mycotoxins and Animal Foods. CRS Press Inc., Boca Raton Boston Ann Arbor, 1991, pp. 216-252.

10. Tanaka, T.; Yamamoto, S.; Hasegawa, A.; Aoki, N.; Besling, J.R.; Sugiura, Y.; Ueno, Y. A survey of the natural occurrence of Fusarium mycotoxins, deoxynivalenol, nivalenol and zearalenone, in cereal harvested in the Netherlands. Mycopathologia 1990, 110, 19-22.

11. Trucksess, M.W.; Thomas, F.; Young, K.; Stack, M.E.; Fulguers, W.J.; Page, S.W. Survey of deoxynivalenol in US 1993 wheat and barley crop by enzyme-linked-immunosorbent-assay. J. AOAC Int. 1995.78, 631-636.

12. Placenta, C.M.; D'Mello, J.P.F.; Macdonald, A.M.C. A review of worldwide contamination of cereal grains and animal feed with Fusarium mycotoxins. Ani. Feed Sci. Technol. 1999, 78, 21-37

13. Iqbal, S.Z.; Rehman, B.; Jinap, S.; Akram, N.; Ahmad, M.N.; Sanny, M.; Sukor, R.; Samsudin, N.I. Assessment of fumonisin B1 concentrations in wheat and barley products in the Punjab region of Pakistan. J. Food Prot. 2020a, 83 (8), 1284-1288.

14. Pestka, J.J.; Bondy, J.S. Alterations of immune function following dietary mycotoxin exposure. Can. J. Physiol. Pharmacol. 1990, 68, 1009-1016.

15. Pestka, J.J.; Smolinski, A.T. Deoxynivalenol: toxicology and potential effects on humans. J. Toxicol. Environ. Health, Part B, 2005, 8, 39-69.

16. Hussein, H.S.; Brasel, J.M. Toxicity, metabolism and impact of mycotoxins on humans and animals. Toxicol. 2001, 167, 101-134.

17. Raza, H.M.F.; Asi, M.R.; Maqbool, U. Assessment of deoxynivalenol (don) mycotoxin in corn and wheat grains consumed in central Punjab, Pakistan. Pak. J. Bot. 2020, 52(6), 2205-2210.

18. Iqbal, S.Z.; Usman, S.; Razis, A.F.A.; Ali, N.B.; Saif, T.; Asi, M.R. Assessment of deoxynivalenol in wheat, corn and products and estimation of dietary intake. Int. J. Environ. Res. Public Health, 2020, 17 (15), 5602.

19. European Commission. Commission Regulation No. 1881/2006 of 19 December 2006 setting maximum levels for certain contaminants in foodstuff. Eur. J. Union 2006, 364, 5-24.

20. Iqbal, S.Z.; Asi, M.R.; Ariño, A.; Akram, N.; Zuber, M. Aflatoxin contamination in different fractions of rice from Pakistan and estimation of dietary intakes. Mycotoxin Res. 201228 (3), 175-180.

21. Joint Food and Agriculture Organization/World Health Organization Expert Committee on Food Additives (JECFA). Evaluation of certain food additives and contaminants (Report of the 72nd meeting of the joint FAO/WHO Expert Committee on Food Additives (JECFA)). WHO Technical Report Series, 2010, 958

22. European Commission. Commission Regulation (EC) No. 401/2006 of 23 February 2006 laying down the methods of sampling and analysis for the official control of the levels of mycotoxins in foodstuffs, 2006, (Vol. 70, pp. 12-35)

23. Ok, H.E.; Lee, S.Y.; Chun, H.S. Occurrence and simultaneous determination of nivalenol and deoxynivalenol in rice and bran by HPLC-UV detection and immunoaffinity cleanup. Food Control, 2018, 87, 53-59.

24. Yang, D.; Geng, Z.M.; Ma, H.X.; Yao, J.B.; Zhang, X.; Zhang, P.P.; et al. Establishment of a HPLC-UV method for simultaneous determination of DON, 15AcDON, and 3AcDON in wheat. Acta Agronomica Sinica, 2012, 38, 186-189.

25. Thammawong, M.; Okabe, M.; Kawasaki, T.; Nakagawa, H.; Nagashima, H.; Okadome, H.; et al. Distribution of deoxynivalenol and nivalenol in milling fractions from Fusarium-infected Japanese wheat cultivars. J. Food Prot. 2010, 73, $1817-1823$.

26. Golge, O.; Kabak, B. Occurrence of deoxynivalenol and zearalenone in cereals and cereal products from Turkey. Food Control 2020, 110, 106982.

27. Cerveró, M.C.; Castillo, M.Ã.; Montes, R.; Hernández, E. Determination of trichothecenes, zearalenone and zearalenols in commercially available corn-based foods in Spain. Rev. Iberoam. Micol. 2007, 24, 52-55.

28. Berthiller, F.; Dall'asta, C.; Corradini, R.; Marchelli, R.; Sulyok, M.; Krska, R.; Adam, G.; Schuhmacher, R.. Occurrence of deoxynivalenol and its 3- $\beta$-D-glucoside in wheat and maize. Food Addict. Contam. Part A, 2009, 26, 507-511. 
29. Nobel, P.B.; Dutton, M.F.; Koch, S.H.; Chuturgoon, A.A.; Stoev, S.D.; Mosonik, J.S. Simultaneous occurrence of mycotoxins in human food commodities from Cameroon. Mycotoxin Res. 2010, 26, 47-57.

30. Paladin, J.; Sokolović, M.; Perši, N.; Zadravec, M.; Jaki, V.; Vulić, A. Contamination of maize with deoxynivalenol and zearalenone in Croatia. Food Control 2012, 28, 94-98.

31. Marques, M.F.; Martins, H.M.; Costa, J.M.; Bernardo, F. Co-occurrence of deoxynivalenol and zearalenone in crops marketed in Portugal. Food Addict. Contam. Part B, 2008, 1(2), 130-133.

32. Vidal, A.; Marín, S.; Ramos, A.J.; Cano-Sancho, G.; Sanchis, V. Determination of aflatoxins, deoxynivalenol, ochratoxin A and zearalenone in wheat and oat-based bran supplements sold in the Spanish market. Food Chem. Toxicol. 2013, 53(3), $133-138$.

33. Jajić, I.; Jurić, V.; Glamočić, D.; Abramović, B. Occurrence of deoxynivalenol in maize and wheat in Serbia. Int. J. Mol. Sci. 2008, 9, 2114-2126.

34. Tima, H.; Brückner, A.; Mohácsi-Farkas, C.; Kiskó, G. Fusarium mycotoxins in cereals harvested from Hungarian fields. Food Addict. Contam. Part B, 2016, 9, 127-131.

35. Giménez, I.; Herrera, M.; Escobar, J.; Ferraz, E.; Lorán, S.; Herrera, A.; Ariño, A. Distribution of deoxynivalenol and zearalenone in milled germ during wheat milling and analysis of toxin levels in wheat germ and wheat germ oil. Food Control 2013, 34(2), 268-273.

36. Hirooka, E.Y.; Yamaguchi, M.M.; Aoyama, S.; Sugiura, Y.; Ueno, Y. The natural occurrence of fumonisins in Brazilian corn kernels. Food Addict. Contam. 1996, 13, 173-183.

37. Fernandez, C.; Stack, M.E.; Musser, S.M. Determination of deoxynivalenol in 1991 in US winter and spring wheat by highperformance thin-layer chromatography. J. Assoc. Off. Anal. Chem. Int. 1994, 77, 628-630.

38. Ngoko, Z.; Marasas, W.F.O.; Rheeder, J.P.; Shephard, G.S.; Wingfield, M.J.; Cardwell, K.F. Fungal infection and mycotoxin contamination of maize in the humid forest and the western highlands of Cameroon. Phytoparacitica 2001, 29, 352-360

39. Devegowda G.; Raju, M.V.; Nazar, A.; Swamy, H.V. Mycotoxin picture worldwide: novel solutions for their counteraction. In: Biotechnology in the feed industry. Proceedings of Alltech's 14th Annual Symposium. Nottingham University Press, Nottingham, 1998, pp 241-255.

40. Soriano, J.M.; Dragacci, S. Occurrence of fumonisins in foods. Food Res. Int. 2004, 37, 985-1000.

41. Whitaker, T.B.; Truckess, W.M.; Johansson, A.S.; Giesbrecht, F.G.; Hagler, W.M. Jr.; Bowman D.T. Variability associated with testing shelled corn for fumonisin. J. Assoc. Off. Anal. Chem. Int. 1998, 81,1162- 1168.

42. Iqbal, S.Z.; Rabbani, T.; Asi, M.R.; Jinap, S. Assessment of aflatoxins, ochratoxin A and zearalenone in breakfast cereals. Food Chem. 2014a,.157c, 257-262.

43. World Health Organization (WHO) (2009). Principles and methods for the risk assessment of chemicals in food. Environmental Health Criteria, Vol. 240. Geneva: World Health Organization.

44. Raad, F.; Nasreddine, L.; Hilan, C.; Bartosik, M.; Parent-Massin, D. Dietary exposure to aflatoxins, ochratoxin A and deoxynivalenol from a total diet study in an adult urban Lebanese population. Food Chem. Toxicol. 2014, 73, 35-43.

45. Cano-Sancho, G.; Ramos, V.; Marín, S.; Sanchis, V. Micotoxinas. Estudio de dieta Total en Cataluña 2008-2009; Generalitat de Cataluña: Barcelona, Spain, 2012; pp. 135-140. 